\title{
An Evaluation of the Role of Oxidative Stress in Non-Obstructive Coronary Artery Disease
}

\author{
Nurnajwa Pahimi $1,2 \oplus$, Aida Hanum Ghulam Rasool ${ }^{1,3}$, Zulkefli Sanip ${ }^{4}\left({ }^{1}\right.$, Nur Adilah Bokti $^{2,3}{ }^{\circledR}$, \\ Zurkurnai Yusof ${ }^{2,3}$ and W. Yus Haniff W. Isa ${ }^{2,3, *}$ \\ 1 Pharmacology Vascular Laboratory, Department of Pharmacology, School of Medical Sciences, \\ Universiti Sains Malaysia, Kota Bharu 16150, Malaysia; najwapahimi@student.usm.my (N.P.); \\ aida.rasool@yahoo.com (A.H.G.R.) \\ 2 Cardiology Unit, Department of Medicine, School of Medical Sciences, Universiti Sains Malaysia, \\ Kubang Kerian 16150, Malaysia; nuradilahbokti@usm.my (N.A.B.); zurkurnai@gmail.com (Z.Y.) \\ 3 Department of Internal Medicine, Hospital Universiti Sains Malaysia, Kubang Kerian 16150, Malaysia \\ 4 Central Research Laboratory, School of Medical Sciences, Universiti Sains Malaysia, \\ Kubang Kerian 16150, Malaysia; zulkefli@usm.my \\ * Correspondence: wyhaniff@usm.my; Tel.: +60-9767-3987
}

Citation: Pahimi, N.; Rasool, A.H.G.; Sanip, Z.; Bokti, N.A.; Yusof, Z.; W. Isa, W.Y.H. An Evaluation of the Role of Oxidative Stress in Non-Obstructive Coronary Artery Disease. J. Cardiovasc. Dev. Dis. 2022, 9, 51. https://doi.org/10.3390/ jcdd9020051

Academic Editor: Kelly Smith

Received: 6 December 2021

Accepted: 25 January 2022

Published: 4 February 2022

Publisher's Note: MDPI stays neutral with regard to jurisdictional claims in published maps and institutional affiliations.

Copyright: (C) 2022 by the authors. Licensee MDPI, Basel, Switzerland. This article is an open access article distributed under the terms and conditions of the Creative Commons Attribution (CC BY) license (https:// creativecommons.org/licenses/by/ $4.0 /)$.

\begin{abstract}
Approximately half of all women presenting to the emergency department with angina chest pain do not have obstructive coronary artery disease (CAD) on coronary angiography. This condition is termed non-obstructive coronary artery disease (NOCAD), and includes ischemia with no obstructive coronary artery disease (INOCA) and myocardial infarction with non-obstructive coronary arteries (MINOCA). Oxidative stress has been reported to be involved in the development and progression of CAD. However, a scarcity of studies has assessed a correlation between oxidative stress and NOCAD. Thus, a literature review was performed of available reports on the role of oxidative stress in NOCAD. Possible mechanisms involved in oxidative stress that may contribute to NOCAD were identified and evaluated. A key finding of this literature review was that oxidative stress caused vasoconstriction and endothelial damage, and this results in coronary microvascular dysfunction and vasospasm, which, in turn, lead to the pathogenesis of NOCAD.
\end{abstract}

Keywords: coronary artery disease; non-obstructive coronary artery disease; oxidative stress

\section{Introduction}

Cardiovascular diseases cause approximately one third of all deaths worldwide [1]. According to the American Heart Association, coronary artery disease (CAD) ranks as the most prevalent of all types of cardiovascular disease [1]. CAD remains the primary cause of death in Malaysia and accounted for approximately 15\% of all mortality in 2019, and this figure is increasing steadily [2]. An increasing number of individuals diagnosed with CAD live with chronic disability and poor quality of life [3,4]. In addition, CAD is associated with significant social and economic costs globally [5]. Accordingly, it represents a major challenge to healthcare systems and societies worldwide.

The most common symptom of CAD is angina pectoris [6], which affects approximately 112 million people globally [7]. Angina pectoris is caused by myocardial ischemia, which creates a temporary and reversible imbalance between myocardial blood supply and oxygen demand [7]. This may occur in the presence of a fixed stenosis or as a result of vasospasm of the coronary arteries [8]. A subset of patients who present with symptoms of angina pectoris do not present with obstructive lesions on coronary angiogram, and this condition is referred to as non-obstructive coronary artery disease (NOCAD). Currently, the proposed mechanisms or factors that may explain the pathogenesis of NOCAD include oxidative stress [9-13], coronary vasospasm [14-16], and microvascular endothelial 
dysfunction [11,17-22]. In the current study, a review of the literature on the topic was performed to evaluate the possible role of oxidative stress in the development and progression of NOCAD, with a view to establishing optimal management approaches to the disease, minimizing the disease burden, and improving the quality of life of people with NOCAD.

\section{Oxidative Stress}

Oxidative stress, defined as a disturbance to the balance between the production of reactive oxygen species (ROS) and antioxidant defense, which leads to tissue injury, appears to be involved in the pathogenesis of many diseases, including cardiovascular disease [23-25]. ROS include free radicals, such as superoxide anion and hydroxyl radicals, as well as nonradical molecules, such as hydrogen peroxide and singlet oxygen [23]. Free radicals are formed in large amounts as byproducts of many biochemical processes. ROS are a natural byproduct of normal oxygen metabolism and play an important role in cell signaling and cellular homoeostasis under normal circumstances [26].

The overexpression of ROS (i.e., in excess of antioxidant defense) can damage cell structures, including carbohydrates, nucleic acids, lipids, and proteins, which alters their functions [26]. Antioxidants are present in cells to prevent the damage incurred by oxidative stress. The scavenging of excess ROS is achieved by the antioxidative defense system, which comprises enzymatic antioxidants (i.e., superoxide dismutase (SODs), catalase, and glutathione peroxidase) [12] and non-enzymatic antioxidants (i.e., glutathione (GSH), polyphenols, and vitamins) [27]. ROS are key players in the induction of oxidative stress. They oxidize lipids, proteins, and DNA by repeated free radical attacks, thus causing tissue damage, which leads to lipid peroxidation, protein denaturation, and DNA mutation $[25,28]$.

\section{Sources of Reactive Oxygen Species}

ROS are produced from either endogenous or exogenous sources. Endogenous sources of ROS, for example, mitochondria, peroxisomes, and endoplasmic reticulum, all have high oxygen consumption levels [29]. Exogenous sources of ROS include environmental pollution, radiation, cigarette smoking, certain foods, and drugs [30]. Major examples of ROS include superoxide, hydrogen peroxide, hydroxyl anions, hydroxyl radicals, and hypochlorous acid [31].

In addition, cellular sources of ROS are divided into two main groups-those that result from biological processes, mainly produced by mitochondrial oxidative metabolism where ROS are released as a byproduct or waste product of various reactions, and those that are released as a result of cellular responses to cytokines, xenobiotics, or bacterial invasion. Thus, ROS are produced through molecular synthesis or breakdown, or as part of a signal transduction pathway or cellular defense mechanism [32].

Most cellular ROS sources are partially reduced forms of oxygen and its derivatives, which result from a one-electron oxygen reduction reaction that produces a superoxide anion. Superoxide, which is also generated by cellular redox enzymes, such as nicotinamide adenine dinucleotide phosphate oxidase, stimulated via receptor-mediated mechanisms, is a byproduct of mitochondrial respiration [33]. Hydrogen peroxide, generated from the dismutation of superoxide, is produced due to various enzymatic reactions, and this occurs spontaneously or is catalyzed by SOD [34]. Hydrogen peroxide is also produced by a two-electron enzymatic reduction of molecular oxygen by various oxidases (e.g., xanthine oxidase) [35]. Superoxide reacts rapidly with nitric oxide (NO) to form peroxynitrite [36].

ROS are associated with physiological and pathological biochemical reactions. Under physiological conditions, ROS act as signaling molecules and play a role in maintaining the redox balance. ROS are an important regulator of redox signaling in the heart as they are involved in multiple physiological processes, including differentiation, proliferation, and cardiac excitation-contraction coupling [37]. ROS act by activating ryanodine receptor $\mathrm{Ca}^{2+}$ release channels in the junctional sarcoplasmic reticulum in the cardiac muscle, which increases the microscopic release of the $\mathrm{Ca}^{2+}$ and modulates the excitation-contraction 
coupling process. In the heart, the redox balance is critical to maintaining the proper functioning of cellular vital functions, such as excitation-contraction coupling, cell differentiation, homeostasis, and functions related to the stress response pathway, such as adaptation to ischemia $[32,38-40]$.

Under pathological conditions, increased ROS levels induce excessive oxidative stress, critically contributing to the pathogenesis and development of various chronic and degenerative diseases, such as cardiovascular disease, diabetes mellitus, Alzheimer's disease, chronic kidney disease, multiple sclerosis, inflammation, aging, and cancer [25,41-44]. Oxidative stress is associated with cardiovascular risk factors and adverse outcomes $[45,46]$ related to the vascular system. Increased levels of oxidative stress enhance the formation of oxidized low-density lipoprotein (LDL) which is rapidly taken up by macrophages in the arterial wall, thus transforming these cells into foam cells [47-49]. Macrophage-derived foam cells are believed to play an important role in the development and progression of atherosclerosis through the production of various bioactive molecules [50,51]. Increased levels of ROS also degrade vascular NO, which leads to a reduction in NO bioavailability, and, in turn, vasoconstriction [52].

Kugiyama et al. reported high levels of plasma-oxidized LDL in patients with coronary artery spasm, compared to the control group. High levels of oxidized LDL correlate with the constrictor reaction of the coronary arteries in response to intracoronary infusion of acetylcholine [53]. Oxidized LDL stimulates the production of endothelin and may contribute to the development of coronary-artery spasm [54]. Thus, higher levels of oxidized LDL have been identified as a risk factors for coronary spasm, as well as having a potential role in its pathogenesis [53].

\section{Consequences of Oxidative Stress}

The endothelium is a single layer of simple squamous cells that lines the interior surface of the blood and lymphatic vessels, positioned between the circulating blood and the vascular wall; it was once considered to function only as a simple passive barrier between the circulating blood and surrounding tissues [55]. However, emerging evidence has shown that the endothelium has multiple functions that are crucial to vascular physiology. It plays an important role in the regulation of vascular tone, platelet activity, leukocyte adhesion, and thrombosis [55]. In addition, it acts as a major regulator of vascular homeostasis, which is responsible for several vasoprotective actions, such as vasodilation, the reduction in smooth muscle cell growth, and inhibition of the inflammatory response [56]. It also controls vascular permeability and prevents platelet aggregation. The endothelium provides endothelium-dependent vasorelaxation in response to vascular stress [57]. It also regulates vascular tone by releasing mediators, such as NO, prostacyclin, and endothelium-derived hyperpolarizing factor, or by causing vasoconstriction through the release of thromboxane A2, endothelin-1, or free radicals [58].

A healthy endothelium reacts to mechanical stimuli, chemical factors, and humoral agents by producing several mediators, such as NO, to maintain vasomotor tone and the structural integrity of vessels. NO is the predominant mediator of vascular tone in conduit vessels and is degraded by free radicals present in conditions of increased oxidative stress [57]. ROS has been shown to cause NO degradation, thereby causing vasoconstriction and endothelial damage [14]. Major sources of NO are generated by endothelial NO synthase, a cytochrome $\mathrm{p} 450$ reductase-like enzyme that uses tetrahydrobiopterin to form NO from L-arginine [57]. NO diffuses into the underlying vascular smooth muscle, which induces smooth muscle relaxation and vasodilation in response to endothelium-dependent vasodilators, such as acetylcholine [59].

\section{Coronary Artery Spasm}

Oxidative stress, endothelial dysfunction, and low-grade chronic inflammation contribute to the pathogenesis of coronary artery spasm. Yamada et al. suggested that oxidative stress by thiol oxidation caused coronary artery spasm, resulting in impaired endothelium- 
dependent vasodilation. The study measured vascular responses in the isolated coronary arteries of two types of rodents (SMP30 KO and wild-type mice) to acetylcholine and sodium nitroprusside [60].

Thiol oxidation is involved in various biological processes; for example, it stimulates changes in protein conformation by transforming free thiols into sulfenic acids, sulfinic acids, sulfonic acids, and disulfide bridges [60]. It has been suggested that thiol oxidation by oxidative stress may trigger coronary artery spasm due to the impairment of endotheliumdependent vasodilation and coronary artery smooth muscle hypercontractility, which leads to increased coronary smooth muscle $\mathrm{Ca}^{2+}$ sensitivity through Rho-kinase activation, ultimately resulting in hypercontraction [61]. In addition, endothelial dysfunction may contribute to coronary artery spasm, which may be mediated by impaired endothelial NO synthase activity or smooth muscle cell contraction with Rho-kinase activation at the spasm site [60].

Thioredoxin is a class of small redox proteins that contains redox-active dithiol/disulfide at the active site. It has a variety of biological functions, including cytoprotection against oxidative stress. Increased thioredoxin production occurs to lessen cellular injury caused by ROS in patients with myocardial ischemia. Thioredoxin is a scavenger of ROS [62]. High levels of thioredoxin could indicate active myocardial ischemia activity [63]. Miyamoto et al. demonstrated that thioredoxin plasma levels were higher in patients with coronary spastic angina, compared to those in the chest pain syndrome group. A large proportion of the patients (i.e., $170 / 240$ ) who were diagnosed with $<25 \%$ stenosis on angiography underwent cardiac catheterization. The participants were further subdivided into two groups. The first group comprised participants with coronary spastic angina and normal coronary angiography ( $n=84$ patients); the second group consisted of participants with chest pain syndrome ( $n=86$ patients) (i.e., the absence of coronary spasm provoked in the coronary arteries). Increased thioredoxin levels correlated with high disease activity, indicated by the frequency of chest pain attacks [64].

Nishihira et al. suggested that thioredoxin was upregulated in patient with unstable angina pectoris due to increased oxidative stress and that it was associated with intraplaque hemorrhage and thrombus formation [65]. Thioredoxin production is induced by oxidative stress, and it is secreted by endothelial cells [66]. In most situations, the cells will activate an adaptive mechanism to protect them from the harmful effects of oxidative stress; however, oxidative stress increases if the oxidant level is persistently greater than the adaptive capability of the cells [67]. Thioredoxin, a sensitive indicator of oxidative stress, could be a potential marker for antioxidative therapy.

Tanabe et al. reported that the levels of serum nitrotyrosine, as oxidative marker, significantly increased after coronary artery vasospasm induced by the acetylcholine provocation test, performed with an injection of acetylcholine through the catheter into the right coronary artery (a dose of either $20 \mu \mathrm{g}$ or $50 \mu \mathrm{g}$ ) and into the left coronary artery (dose of $50 \mu \mathrm{g}$ or $100 \mu \mathrm{g}$ ), both administered within a minute. Coronary angiography was performed three minutes after each injection. A comparison was performed of the serum levels of 4-hydroxynonenal (HNE) and nitrotyrosine in 30 patients with a suspected diagnosis of vasospastic angina following the administration of the acetylcholine provocation test. The HNE levels did not change after the test; yet there was increase in nitrotyrosine concentration in the group of patients who were positive for vasospastic angina [59]. This suggests that peroxynitrite contributed to the pathogenesis of coronary artery vasospasm as nitrotyrosine is recommended to assess oxidative stress in coronary artery spasm rather than HNE. Nitrotyrosine is produced by tyrosine nitration, which is mediated by reactive nitrogen species, including peroxynitrite anion and nitrogen dioxide [68]. It is formed in the presence of the active metabolite, NO. In addition, nitrotyrosine is considered to be a marker for cell damage, inflammation, and NO generation [59].

In their study, Ohba et al. reported that coronary artery spasm was identified by distinctive clinical features in patients with non-obstructive coronary arteries and coronary endothelial dysfunction assessed using the acetylcholine provocation test. The study 
included 370 stable angina patients with suspected non-obstructive coronary arteries $(<50 \%$ stenosis) on coronary angiography who underwent the acetylcholine provocation test, along with the simultaneous measurement of transcardiac lactate production and quantitative coronary blood flow [15]. Increased lactate levels in the coronary circulation indicates signs of myocardial ischemia $[69,70]$.

In the Ohba et al. study, 50 of the 370 patients with microvascular coronary artery spasm demonstrated significant impairment of the endothelium-dependent vascular response using a quantitative assessment of coronary blood flow (i.e., decreased blood flow on the acetylcholine provocation test) [15]. The acetylcholine provocation test is an endothelium-dependent coronary reactivity test used to assess endothelial function and coronary artery spasm. Acetylcholine causes vasodilation when the endothelium is intact by releasing NO; by contrast, acetylcholine produces vasoconstriction when endothelial function is impaired [71,72]. Ludmer et al. determined that paradoxical vasoconstriction induced by acetylcholine took place during the development of coronary atherosclerosis. The authors suggested that an abnormal vascular response to acetylcholine reflected the impairment of endothelial function [72,73], hence contributing to pathogenesis of the coronary artery spasm.

\section{Roles of Oxidative Stress in Non-Obstructive Coronary Artery Disease}

Over the past three decades, evidence has accumulated to elucidate the contribution of oxidative stress to the development of CAD (Table 2); however, few reports are available on role of oxidative stress in patients with NOCAD (Table 1). Şahin et al. reported that oxidative status and C-reactive protein levels in patients with NOCAD were higher than those in the control group. The study compared three groups of subjects $(n=80)$. The first group comprised 33 patients with typical angina who had normal coronary arteries on angiography and a positive stress test; the second group comprised 27 patients with atypical angina who had no evidence of vasospastic angina, normal coronary arteries on angiography, and a negative stress test, and the last group was the control (i.e., healthy subjects). The authors reported that antioxidant status was lower in patients with NOCAD, compared to the control group [12]. In addition, an increase in oxidative stress was linked to endothelial microvascular dysfunction [74]. In the study, oxidative status was measured by total oxidant status, lipid hydroperoxide levels, and an oxidative stress index; antioxidative status was measured by total antioxidant capacity [12], and the finding was that microvascular dysfunction due to coronary endothelial dysfunction caused myocardial ischemia in patients with NOCAD owing to the overproduction of oxidative stress [12,75].

Table 1. Reports on oxidative stress in NOCAD.

\begin{tabular}{|c|c|c|}
\hline Parameters & Findings & References \\
\hline $\begin{array}{l}\text { Total oxidant status, lipid hydroperoxide } \\
\text { levels and oxidative stress index }\end{array}$ & Oxidant levels were high in patients with cardiac syndrome $X$. & [12] \\
\hline $\mathrm{MDA}^{1}, \mathrm{GSH}^{2}$, and $\mathrm{SOD}^{3}$ activity & $\begin{array}{l}\text { An increase in the levels of MDA }{ }^{1} \text {, an oxidative stress marker, } \\
\text { along with a decrease in the levels of major important } \\
\text { antioxidants, such as FRAP }{ }^{4} \text { and GSH }{ }^{2} \text {, and a reduction in } \\
\text { SOD }^{3} \text { activity was demonstrated in patients with cardiac } \\
\text { syndrome } X \text {, compared to the healthy controls. }\end{array}$ & [76] \\
\hline Asian dust & $\begin{array}{l}\text { Short-term exposure to Asian dust was associated with a high } \\
\text { risk of MINOCA }{ }^{5} \text {. }\end{array}$ & [63] \\
\hline Cystine & Cystine levels increased in patients with INOCA ${ }^{6}$. & [45] \\
\hline
\end{tabular}

${ }^{1} \mathrm{MDA}$, malondialdehyde; ${ }^{2} \mathrm{GSH}$, glutathione; ${ }^{3} \mathrm{SOD}$, superoxide dismutase; ${ }^{4} \mathrm{FRAP}$, ferric reducing ability of plasma; ${ }^{5}$ MINOCA, myocardial infarction with no obstructive coronary artery disease; ${ }^{6}$ INOCA, ischemia with no obstructive coronary artery disease.

Seydi-Shirvani et al. reported an increase in malondialdehyde (MDA) levels and a significant decrease in levels of ferric reducing ability of plasma (FRAP), GSH levels, and SOD activity in patients with NOCAD, compared to a healthy control group [76]. 
MDA, a highly reactive three-carbon dialdehyde, is produced by the peroxidation of polyunsaturated fatty acid and is used as a marker of oxidative stress [77]. It is also produced by the metabolism of arachidonic acid, which is catalyzed by the enzyme, cyclooxygenase [78]. During oxidative stress, ROS triggers the peroxidation of membrane lipids, which results in the formation of MDA [77]. GSH levels and SOD activity are used to measure antioxidant markers and FRAP is used as a marker of total antioxidant capacity. FRAP refers to the capacity of antioxidant defense system to reduce or break down ROS. It can serve as an indicator of the susceptibility of antioxidants to the damage caused by oxidative stress. Changes in antioxidant levels reflect a compensatory mechanism used to counteract the increased levels of oxidative stress identified in patients with NOCAD [76]. Antioxidant defense mechanisms counteract the accumulation of ROS by scavenging and converting ROS to non-toxic molecules to reduce oxidative-stress-related damage. The contribution of oxidative stress to the development of NOCAD can also be evaluated by SOD activity. SODs have an important role in protection against lipid peroxidation and are recognized as the major antioxidant enzyme defense systems in the arterial vessel wall [76], and extracellular SODs are extracellular scavengers of superoxide anion in the vessel wall [62].

Ishii et al. suggested that Asian dust caused oxidative stress and inflammation associated with the development of myocardial infarction with non-obstructive coronary arteries (MINOCA) [63]. Asian dust, also known as yellow sand, is a meteorological phenomenon in East Asia, especially in spring. The dust originates in the deserts of East Asia and is spread by prevailing winds to China and Mongolia. Asian dust contains natural mineral soil, microorganisms, and anthropogenic hazardous components produced by factories that use fuels and by automobiles, and these components bind to the particles during transportation [79]. Short-term exposure to Asian dust is associated with a higher risk of MINOCA than obstructive CAD.

The study by Ishii et al. in Japan assessed the association of admission of individuals with myocardial infarction with obstructive CAD and that of individuals with MINOCA to hospital after the occurrence two days earlier of Asian-dust events. The admission of individuals to hospital for MINOCA, after adjusting for meteorological variables, was found to correlate with Asian-dust events; however, a correlation was not established between the admission of individuals with myocardial infarction with obstructive CAD to hospital and the dust events. The absolute difference in the risk of MINOCA admission was 1.79 per 100,000 person-years [63]. The chemical analysis of Asian-dust-storm particles showed that the particles contained complex organic matter, elemental carbon, ammonium ions, sulfate ions, nitrate ions, and heavy metals, which may have contributed to oxidative stress [80].

In support of these findings, Chuang et al. proposed that the inhaled particles of urban air pollution induced systemic oxidative stress measured by 8-hydroxy-2'-deoxyguanosine, and the inhalation of polluted particles was also associated with cardiovascular events $[81,82]$. The findings of the study by Lee et al. further support the association between particulate matters (particle pollution) that cause oxidative stress and the induction of endothelial dysfunction and systemic inflammation, leading to cardiovascular events [83]. The study was conducted on community adults in a densely populated inner city neighborhood in Boston, Massachusetts, USA. The authors suggested that oxidative stress and systemic inflammation aggravated the adverse effects of fine particulate matter on cardiac autonomic function, even when the individuals were exposed to low pollutant levels [83].

Huang et al. reported that autonomic and vascular dysfunction increased cardiovasculardisease risk following exposure to high air-pollution levels [84]. Exposure to high levels of black carbon was established to be an oxidative-stress marker that independently correlated with major adverse cardiovascular events one month after exposure in patients presenting with acute coronary syndrome. Black carbon is a traffic-related particle that is a byproduct of combustion [85]. Therefore, populations that reside in urban and industrial areas are at a high risk of developing CAD, especially NOCAD. 
An association was established in the study by Raad et al. between oxidative stress and diastolic dysfunction in patients with ischemia with no obstructive coronary artery disease (INOCA). An increase in aminothiol cysteine levels is often used as oxidativestress marker, and it is associated with impaired endothelial function, increased arterial stiffness, carotid atherosclerosis, myocardial stiffness, and high rates of adverse cardiovascular events [45]. Cysteine thiols are significantly involved in oxidative-stress conditions. Cysteine is a primary aminothiol extracellular source that undergoes oxidation to form cysteine disulfide [86]. The study by Raad et al. showed that the role of oxidative stress in the pathogenesis of heart failure was not restricted to obstructive CAD and INOCA [45]. The authors suggested that systemic oxidative stress, measured by aminothiol cystine levels, was associated with diastolic dysfunction, even after adjusting for other underlying diseases that may have impacted diastolic function [45]. Oxidative stress has been shown to contribute to pathological hypertrophy, pathological remodeling, and the development and progression of cardiac failure [87,88]. In addition, the role of oxidative stress in heart failure was demonstrated in gene-transfer studies on primary antioxidant enzymes (SODs, catalase, and glutathione peroxidase), thioredoxin, and heme oxygenase-1 [87].

Ide et al. reported that left ventricular contractile failure was associated with oxidative stress. The increased production of ROS could have a role in the pathophysiology of heart failure. The study, conducted on adult mongrel dogs showed an increase in the production of hydroxyl radicals, originating from superoxide and hydrogen peroxide in the failing myocardium [89]. Thus, oxidative stress was seen to contribute to the development of NOCAD and to the pathogenesis of heart failure.

Table 2. Reports on oxidative stress in CAD.

\begin{tabular}{|c|c|c|}
\hline Parameters & Findings & References \\
\hline Thioredoxin & $\begin{array}{c}\text { Glucose intolerance with } \mathrm{CAD}^{1} \text { was linked to high levels of thioredoxin, an } \\
\text { oxidative stress marker. }\end{array}$ & [66] \\
\hline MDA $^{2}$ & $\begin{array}{l}\text { The plasma levels of } \mathrm{MDA}^{2} \text {-modified } \mathrm{LDL}^{3} \text { were significantly higher in } \\
\text { patients with acute coronary syndrome than patients with stable CAD }{ }^{1} \text {, and } \\
\text { this correlated with increased levels of troponin I and C-reactive protein. }\end{array}$ & [90] \\
\hline $\begin{array}{l}\text { Aminothiols, cystine, } \\
\text { glutathione, and } \\
\text { cystine/glutathione ratio }\end{array}$ & $\begin{array}{l}\text { High burdens of oxidative stress were quantified by plasma aminothiols, } \\
\text { cystine, glutathione, and their ratio, was associated with mortality in patients } \\
\text { with } \text { CAD }^{1}\end{array}$ & [91] \\
\hline $\mathrm{CyPA}^{4}$ & $\begin{array}{c}\begin{array}{c}\text { Plasma CyPA }{ }^{4} \text { level was a novel biomarker for oxidative stress and } \mathrm{CAD}^{1} \text { in } \\
\text { humans. }\end{array}\end{array}$ & [92] \\
\hline $\begin{array}{l}\mathrm{MDA}^{2}, \mathrm{O}_{2} \text {, and } \mathrm{SOD}^{5} \\
\text { activity }\end{array}$ & $\begin{array}{c}\text { Level of MDA }{ }^{2} \text { and } \mathrm{O}_{2}-\text { in plasma were significantly higher with lower level } \\
\text { of SOD }{ }^{4} \text { activity in patients with CAD }{ }^{1} \text {. }\end{array}$ & [93] \\
\hline Ox-LDL ${ }^{6}$ & $\begin{array}{l}\text { Ox-LDL }^{6} \text {, ox-LDL }{ }^{6} / \text { total cholesterol, ox-LDL }^{6} / \text { HDL-C }^{7}, \text { ox-LDL }^{6} / \\
\text { LDL-C }^{8} \text {, and ox-LDL } \\
\text { patients and subjects with hypertension and/or diabetes. }\end{array}$ & [94] \\
\hline $\begin{array}{l}\text { Lipid hydroperoxide, total antioxidant status, } \\
\text { total oxidant status, oxidative stress index, } \\
\text { paraoxonase, and arylesterase activities }\end{array}$ & $\begin{array}{l}\text { High oxidative stress index values and elevated total oxidant status levels } \\
\text { were associated with disease severity, vascular damage and there was strong } \\
\text { correlation with heavy smoking in the early development of CAD }\end{array}$ & [95] \\
\hline MDA $^{2}$ and erythrocytes $\mathrm{SOD}^{4}$ activity & $\begin{array}{l}\text { An increase in } \mathrm{MDA}^{2} \text { plasma levels and a corresponding decrease in } \\
\text { glutathione and glutathione peroxidase levels may serve as potential } \\
\text { biomarkers for detecting the early development of atherosclerosis. }\end{array}$ & [96] \\
\hline Ox-LDL ${ }^{5}$ & $\begin{array}{c}\text { High ox-LDL }{ }^{6} \text { levels showed a significant positive correlation with the } \\
\text { severity of acute coronary syndrome. Severe lesions contained a significantly } \\
\text { higher percentage of ox-LDL }{ }^{6} \text {-positive macrophages, suggesting that } \\
\text { increased levels of ox-LDL }{ }^{6} \text { correlated with plaque instability in coronary } \\
\text { atherosclerotic lesions. }\end{array}$ & [97] \\
\hline $\begin{array}{l}\text { Platelet aggregation, } \mathrm{MDA}^{2} \text {, plasma-ionized } \\
\text { Ca21, and antioxidant enzymes (glutathione } \\
\text { peroxidase and } \mathrm{SOD}^{4} \text { ) }\end{array}$ & $\begin{array}{c}\text { Platelet aggregation and the plasma levels of } \mathrm{MDA}^{2} \text { and plasma-ionized Ca21 } \\
\text { increased significantly in patients with CAD }{ }^{1} \text {, compared to the control group. } \\
\text { A decrease in antioxidant enzymes activity was observed with the exception } \\
\text { of a slight increase in glutathione peroxidase levels in patients with } \\
\text { myocardial infarction. }\end{array}$ & [98] \\
\hline
\end{tabular}




\section{Burden of Non-Obstructive Coronary Artery Disease and Related Implications}

Elsewhere, patients with NOCAD had higher rates of typical angina at follow-up, catheterization, and rehospitalization for unstable angina, as well as increased nitroglycerin use, compared to healthy individuals [99]. Groepenhoff et al. reported that clinic-based consultations between general practitioners and patients with non-obstructed coronary arteries were significantly higher for cardiovascular complaints (89\%), compared with asymptomatic subjects (34\%) [100]. In general, patients with NOCAD experience recurrent angina, which results in ongoing anxiety and a poor quality of life [22,101]. Individuals with NOCAD are also at high risk of cardiovascular adverse events and the associated socioeconomic impact and burden to individuals, families, and countries [102-104]. Factors that contribute to the pathogenesis of NOCAD, such as oxidative stress, should be addressed in treatment strategies that target this group of subjects, with a view to reducing the socioeconomic burden; in addition, they could constitute new potential predictors of prognosis and disease severity [105].

\section{Conclusions}

Oxidative stress can cause vasoconstriction and endothelial damage, resulting in coronary microvascular dysfunction and coronary vasospasm, which, in turn, leads to the pathogenesis of NOCAD. Although there is evidence from animal and human studies of the role of oxidative stress in cardiovascular disorders, antioxidant applications remain ineffective in preventing cardiovascular mortality. A better understanding of redox reactions and development of targeted antioxidants is important for the broad implementation of pharmacological therapies for cardiovascular diseases. Further advanced research on oxidative stress is needed to achieve this, especially to elucidate the role of oxidative stress in NOCAD.

Author Contributions: Conceptualization and critical review, W.Y.H.W.I., A.H.G.R., and Z.Y.; writing—original draft preparation, N.P., Z.S., and N.A.B.; writing—review and editing, N.P. All authors have read and agreed to the published version of the manuscript.

Funding: This research was funded by Fundamental Research Grant Scheme (FRGS), with Project Code: FRGS/1/2019/SKK03/USM/02/5.

Acknowledgments: Acknowledgement to "Ministry of Higher Education Malaysia" for FRGS with Project Code: FRGS/1/2019/SKK03/USM/02/5.

Conflicts of Interest: The authors declare no conflict of interest.

\section{Abbreviations}

$\begin{array}{ll}\text { CAD } & \text { Coronary artery disease } \\ \text { CyPA } & \text { Plasma cyclophilin A } \\ \text { FRAP } & \text { Ferric reducing ability of plasma } \\ \text { GSH } & \text { Glutathione } \\ \text { HDL-C } & \text { High-density lipoprotein-cholesterol } \\ \text { HNE } & \text { 4-hydroxynonenal } \\ \text { INOCA } & \text { Ischemia with no obstructive coronary artery disease } \\ \text { LDL } & \text { Low-density lipoprotein } \\ \text { LOOH } & \text { Lipid hydroperoxide level } \\ \text { MDA } & \text { Malondialdehyde } \\ \text { MINOCA } & \text { Myocardial ischemia with no obstructive coronary artery disease } \\ \text { NO } & \text { Nitric oxide } \\ \text { NOCAD } & \text { Non-obstructive coronary artery disease } \\ \text { OX-LDL } & \text { Oxidized low-density lipoprotein } \\ \text { ROS } & \text { Reactive oxygen species } \\ \text { SOD } & \text { Superoxide dismutase }\end{array}$




\section{References}

1. Virani, S.S.; Alonso, A.; Aparicio, H.J.; Benjamin, E.J.; Bittencourt, M.S.; Callaway, C.W.; Carson, A.P.; Chamberlain, A.M.; Cheng, S.; Delling, F.N.; et al. Heart Disease and Stroke Statistics-2021 Update: A Report From the American Heart Association. Circulation 2021, 143, e254-e743. [CrossRef] [PubMed]

2. Department of Statistics Malaysia Official Portal. Available online: https://www.dosm.gov.my/v1/index.php?r=column/ cthemeB-Cat\&cat=401\&bul_id=QTU5T0dKQ1g4MHYxd3ZpMzhEMzdRdz09\&menu_id=L0pheU43NWJwRWVSZklWdzQ4 TlhUUT09 (accessed on 6 December 2021).

3. Srivastava, S.; Shekhar, S.; Bhatia, M.S.; Dwivedi, S. Quality of Life in Patients with Coronary Artery Disease and Panic Disorder: A Comparative Study. Oman Med. J. 2017, 32, 20-26. [CrossRef] [PubMed]

4. Klocek, M.; Kawecka-Jaszcz, K. Quality of life in patients with essential arterial hypertension. Part I: The effect o sociodemographic factors. Przegl. Lek. 2003, 60, 92-100. [PubMed]

5. Gheorghe, A.; Griffiths, U.; Murphy, A.; Legido-Quigley, H.; Lamptey, P.; Perel, P. The Economic Burden of Cardiovascular Disease and Hypertension in Low- and Middle-Income Countries: A Systematic Review. BMC Public Health 2018, 18, 975. [CrossRef]

6. Gandhi, M.M.; Lampe, F.C.; Wood, D.A. Incidence, Clinical Characteristics, and Short-Term Prognosis of Angina Pectoris. Heart 1995, 73, 193-198. [CrossRef]

7. MOH. Clinical Practice Guidelines of Coronary Stable Disease Artery 2018, 2nd ed.; National Heart Association of Malaysia: Kuala Lumpur, Malaysia, 2018; Volume 97.

8. $\quad$ Andersson, H.B.; Pedersen, F.; Engstrøm, T.; Helqvist, S.; Jensen, M.K.; Jørgensen, E.; Kelbæk, H.; Räder, S.B.E.W.; Saunamäki, K.; Bates, E.; et al. Long-Term Survival and Causes of Death in Patients with ST-Elevation Acute Coronary Syndrome without Obstructive Coronary Artery Disease. Eur. Heart J. 2018, 39, 102-110. [CrossRef]

9. Van de Wouw, J.; Sorop, O.; van Drie, R.W.A.; van Duin, R.W.B.; Nguyen, I.T.N.; Joles, J.A.; Verhaar, M.C.; Merkus, D.; Duncker, D.J. Perturbations in Myocardial Perfusion and Oxygen Balance in Swine with Multiple Risk Factors: A Novel Model of Ischemia and No Obstructive Coronary Artery Disease. Basic Res. Cardiol. 2020, 115, 21. [CrossRef]

10. Severino, P.; d'Amato, A.; Pucci, M.; Infusino, F.; Adamo, F.; Birtolo, L.I.; Netti, L.; Montefusco, G.; Chimenti, C.; Lavalle, C.; et al. Ischemic Heart Disease Pathophysiology Paradigms Overview: From Plaque Activation to Microvascular Dysfunction. Int. J. Mol. Sci. 2020, 21, E8118. [CrossRef]

11. Cannon, R.O. Microvascular Angina and the Continuing Dilemma of Chest Pain with Normal Coronary Angiograms. J. Am. Coll. Cardiol. 2009, 54, 877-885. [CrossRef]

12. Şahin, D.Y.; Elbasan, Z.; Gür, M.; Türkoğlu, C.; Özaltun, B.; Sümbül, Z.; Çaylı, M. Relationship between Oxidative Stress Markers and Cardiac Syndrome, X.J. Clin. Exp. Investig. 2012, 3, 174-180. [CrossRef]

13. Chaudhary, R.; Sukhi, A.; Chaudhary, R.; Jindal, M.; Vyas, A.; Rout, A.; Bliden, K.; Tantry, U.; Gurbel, P. Gender Differences in Thrombogenicity among Patients with Angina and Non-Obstructive Coronary Artery Disease. J. Thromb. Thrombolysis 2019, 48, 373-381. [CrossRef]

14. Matta, A.; Bouisset, F.; Lhermusier, T.; Campelo-Parada, F.; Elbaz, M.; Carrié, D.; Roncalli, J. Coronary Artery Spasm: New Insights. J. Interv. Cardiol. 2020, 2020, 5894586. [CrossRef]

15. Ohba, K.; Sugiyama, S.; Sumida, H.; Nozaki, T.; Matsubara, J.; Matsuzawa, Y.; Konishi, M.; Akiyama, E.; Kurokawa, H.; Maeda, H.; et al. Microvascular Coronary Artery Spasm Presents Distinctive Clinical Features with Endothelial Dysfunction as Nonobstructive Coronary Artery Disease. J. Am. Heart Assoc. 2012, 1, e002485. [CrossRef]

16. Buchthal, S.D.; den Hollander, J.A.; Merz, C.N.; Rogers, W.J.; Pepine, C.J.; Reichek, N.; Sharaf, B.L.; Reis, S.; Kelsey, S.F.; Pohost, G.M. Abnormal Myocardial Phosphorus-31 Nuclear Magnetic Resonance Spectroscopy in Women with Chest Pain but Normal Coronary Angiograms. N. Engl. J. Med. 2000, 342, 829-835. [CrossRef]

17. Doyle, M.; Weinberg, N.; Pohost, G.M.; Bairey Merz, C.N.; Shaw, L.J.; Sopko, G.; Fuisz, A.; Rogers, W.J.; Walsh, E.G.; Johnson, B.D.; et al. Prognostic Value of Global MR Myocardial Perfusion Imaging in Women with Suspected Myocardial Ischemia and No Obstructive Coronary Disease: Results from the NHLBI-Sponsored WISE (Women's Ischemia Syndrome Evaluation) Study. JACC Cardiovasc. Imaging 2010, 3, 1030-1036. [CrossRef]

18. Bourassa, M.G.; Butnaru, A.; Lespérance, J.; Tardif, J.-C. Symptomatic Myocardial Bridges: Overview of Ischemic Mechanisms and Current Diagnostic and Treatment Strategies. J. Am. Coll. Cardiol. 2003, 41, 351-359. [CrossRef]

19. Anderson, R.D.; Petersen, J.W.; Mehta, P.K.; Wei, J.; Johnson, B.D.; Handberg, E.M.; Kar, S.; Samuels, B.; Azarbal, B.; Kothawade, K.; et al. Prevalence of Coronary Endothelial and Microvascular Dysfunction in Women with Symptoms of Ischemia and No Obstructive Coronary Artery Disease Is Confirmed by a New Cohort: The NHLBI-Sponsored Women's Ischemia Syndrome Evaluation-Coronary Vascular Dysfunction (WISE-CVD). J. Interv. Cardiol. 2019, 2019, 7169275. [CrossRef]

20. Michelsen, M.M.; Mygind, N.D.; Pena, A.; Aziz, A.; Frestad, D.; Høst, N.; Prescott, E.; Steering Committee of the iPOWER Study. Peripheral Reactive Hyperemia Index and Coronary Microvascular Function in Women with No Obstructive CAD: The IPOWER Study. JACC Cardiovasc. Imaging 2016, 9, 411-417. [CrossRef]

21. Sara, J.D.; Taher, R.; Kolluri, N.; Vella, A.; Lerman, L.O.; Lerman, A. Coronary Microvascular Dysfunction Is Associated with Poor Glycemic Control amongst Female Diabetics with Chest Pain and Non-Obstructive Coronary Artery Disease. Cardiovasc. Diabetol. 2019, 18, 22. [CrossRef] 
22. Sara, J.D.; Widmer, R.J.; Matsuzawa, Y.; Lennon, R.J.; Lerman, L.O.; Lerman, A. Prevalence of Coronary Microvascular Dysfunction Among Patients with Chest Pain and Nonobstructive Coronary Artery Disease. JACC Cardiovasc. Interv. 2015, 8, 1445-1453. [CrossRef]

23. Sharma, P.; Jha, A.B.; Dubey, R.S.; Pessarakli, M. Reactive Oxygen Species, Oxidative Damage, and Antioxidative Defense Mechanism in Plants under Stressful Conditions. J. Bot. 2012, 2012, 1-26. [CrossRef]

24. Kura, B.; Szeiffova Bacova, B.; Kalocayova, B.; Sykora, M.; Slezak, J. Oxidative Stress-Responsive MicroRNAs in Heart Injury. Int. J. Mol. Sci. 2020, 21, E358. [CrossRef]

25. Vichova, T.; Motovska, Z. Oxidative Stress: Predictive Marker for Coronary Artery Disease. Exp. Clin. Cardiol. 2013, 18, e88-e91. [PubMed]

26. Snezhkina, A.V.; Kudryavtseva, A.V.; Kardymon, O.L.; Savvateeva, M.V.; Melnikova, N.V.; Krasnov, G.S.; Dmitriev, A.A. ROS Generation and Antioxidant Defense Systems in Normal and Malignant Cells. Oxid. Med. Cell. Longev. 2019, $2019,6175804$. [CrossRef] [PubMed]

27. D'Oria, R.; Schipani, R.; Leonardini, A.; Natalicchio, A.; Perrini, S.; Cignarelli, A.; Laviola, L.; Giorgino, F. The Role of Oxidative Stress in Cardiac Disease: From Physiological Response to Injury Factor. Oxid. Med. Cell. Longev. 2020, 2020, 5732956. [CrossRef]

28. Ho, E.; Karimi Galougahi, K.; Liu, C.-C.; Bhindi, R.; Figtree, G.A. Biological Markers of Oxidative Stress: Applications to Cardiovascular Research and Practice. Redox Biol. 2013, 1, 483-491. [CrossRef]

29. Phaniendra, A.; Jestadi, D.B.; Periyasamy, L. Free Radicals: Properties, Sources, Targets, and Their Implication in Various Diseases. Indian J. Clin. Biochem. IJCB 2015, 30, 11-26. [CrossRef] [PubMed]

30. Elsayed Azab, A.; Adwas, A.; Ibrahim Elsayed, A.S.; Adwas, A.; Ibrahim Elsayed, A.S.; Quwaydir, F.A. Oxidative Stress and Antioxidant Mechanisms in Human Body. J. Appl. Biotechnol. Bioeng. 2019, 6, 43-47. [CrossRef]

31. Mittal, M.; Siddiqui, M.R.; Tran, K.; Reddy, S.P.; Malik, A.B. Reactive Oxygen Species in Inflammation and Tissue Injury. Antioxid. Redox Signal 2014, 20, 1126-1167. [CrossRef]

32. Zhang, J.; Wang, X.; Vikash, V.; Ye, Q.; Wu, D.; Liu, Y.; Dong, W. ROS and ROS-Mediated Cellular Signaling. Oxid. Med. Cell. Longev. 2016, 2016, 4350965. [CrossRef]

33. Lambeth, J.D. NOX Enzymes and the Biology of Reactive Oxygen. Nat. Rev. Immunol. 2004, 4, 181-189. [CrossRef]

34. Liochev, S.I.; Fridovich, I. The Effects of Superoxide Dismutase on H2O2 Formation. Free Radic. Biol. Med. 2007, 42, 1465-1469. [CrossRef]

35. Handy, D.E.; Lubos, E.; Yang, Y.; Galbraith, J.D.; Kelly, N.; Zhang, Y.-Y.; Leopold, J.A.; Loscalzo, J. Glutathione Peroxidase-1 Regulates Mitochondrial Function to Modulate Redox-Dependent Cellular Responses. J. Biol. Chem. 2009, 284, 11913-11921. [CrossRef]

36. Pryor, W.A.; Squadrito, G.L. The Chemistry of Peroxynitrite: A Product from the Reaction of Nitric Oxide with Superoxide. Am. J. Physiol. 1995, 268, L699-L722. [CrossRef]

37. Roy, J.; Galano, J.-M.; Durand, T.; Le Guennec, J.-Y.; Lee, J.C.-Y. Physiological Role of Reactive Oxygen Species as Promoters of Natural Defenses. FASEB J. 2017, 31, 3729-3745. [CrossRef]

38. Valko, M.; Leibfritz, D.; Moncol, J.; Cronin, M.T.D.; Mazur, M.; Telser, J. Free Radicals and Antioxidants in Normal Physiological Functions and Human Disease. Int. J. Biochem. Cell Biol. 2007, 39, 44-84. [CrossRef]

39. Dröge, W. Free Radicals in the Physiological Control of Cell Function. Physiol. Rev. 2002, 82, 47-95. [CrossRef]

40. Burgoyne, J.R.; Mongue-Din, H.; Eaton, P.; Shah, A.M. Redox Signaling in Cardiac Physiology and Pathology. Circ. Res. 2012, 111, 1091-1106. [CrossRef]

41. Menzel, A.; Samouda, H.; Dohet, F.; Loap, S.; Ellulu, M.S.; Bohn, T. Reply to Mrakic-Sposta et al. Comment on "Menzel et al Common and Novel Markers for Measuring Inflammation and Oxidative Stress Ex Vivo in Research and Clinical Practice-Which to Use Regarding Disease Outcomes? Antioxidants 2021, 10, 414. [CrossRef]

42. Vassalle, C.; Maltinti, M.; Sabatino, L. Targeting Oxidative Stress for Disease Prevention and Therapy: Where Do We Stand, and Where Do We Go from Here. Molecules 2020, 25, 2653. [CrossRef]

43. Scutiero, G.; Iannone, P.; Bernardi, G.; Bonaccorsi, G.; Spadaro, S.; Volta, C.A.; Greco, P.; Nappi, L. Oxidative Stress and Endometriosis: A Systematic Review of the Literature. Oxid. Med. Cell. Longev. 2017, 2017, 7265238. [CrossRef] [PubMed]

44. Denollet, J.; Sys, S.U.; Brutsaert, D.L. Personality and Mortality after Myocardial Infarction: Psychosom. Med. 1995, 57, 582-591. [CrossRef] [PubMed]

45. Raad, M.; AlBadri, A.; Wei, J.; Mehta, P.K.; Maughan, J.; Gadh, A.; Thomson, L.; Jones, D.P.; Quyyumi, A.A.; Pepine, C.J.; et al. Oxidative Stress Is Associated with Diastolic Dysfunction in Women with Ischemia with No Obstructive Coronary Artery Disease. J. Am. Heart Assoc. 2020, 9, e015602. [CrossRef] [PubMed]

46. Heitzer, T.; Schlinzig, T.; Krohn, K.; Meinertz, T.; Münzel, T. Endothelial Dysfunction, Oxidative Stress, and Risk of Cardiovascular Events in Patients with Coronary Artery Disease. Circulation 2001, 104, 2673-2678. [CrossRef]

47. Maiolino, G.; Pedon, L.; Cesari, M.; Frigo, A.C.; Barisa, M.; Rossitto, G.; Seccia, T.M.; Zanchetta, M.; Rossi, G.P. Antibodies to Malondialdehyde Oxidized Low-Density Lipoproteins Predict Long Term Cardiovascular Mortality in High Risk Patients. Int. J. Cardiol. 2013, 168, 484-489. [CrossRef]

48. Moore, K.J.; Sheedy, F.J.; Fisher, E.A. Macrophages in Atherosclerosis: A Dynamic Balance. Nat. Rev. Immunol. 2013, 13, 709-721. [CrossRef] 
49. Steinberg, D. Low Density Lipoprotein Oxidation and Its Pathobiological Significance. J. Biol. Chem. 1997, 272, $20963-20966$. [CrossRef]

50. Shashkin, P.; Dragulev, B.; Ley, K. Macrophage Differentiation to Foam Cells. Curr. Pharm. Des. 2005, 11, 3061-3072. [CrossRef]

51. Bekkering, S.; Quintin, J.; Joosten, L.A.B.; van der Meer, J.W.M.; Netea, M.G.; Riksen, N.P. Oxidized Low-Density Lipoprotein Induces Long-Term Proinflammatory Cytokine Production and Foam Cell Formation via Epigenetic Reprogramming of Monocytes. Arterioscler. Thromb. Vasc. Biol. 2014, 34, 1731-1738. [CrossRef]

52. Senoner, T.; Dichtl, W. Oxidative Stress in Cardiovascular Diseases: Still a Therapeutic Target? Nutrients 2019, 11, 2090. [CrossRef]

53. Kugiyama, K.; Sugiyama, S.; Soejima, H.; Kawano, H.; Sakamoto, T.; Takazoe, K.; Ogawa, H.; Doi, H.; Yasue, H. Increase in Plasma Levels of Oxidized Low-Density Lipoproteins in Patients with Coronary Spastic Angina. Atherosclerosis 2001, 154, 463-467. [CrossRef]

54. Li, L.; Jin, Y.-P.; Xia, S.-D.; Feng, C. The Biochemical Markers Associated with the Occurrence of Coronary Spasm. BioMed Res. Int. 2019, 2019, 4834202. [CrossRef]

55. Galley, H.F.; Webster, N.R. Physiology of the Endothelium. Br. J. Anaesth. 2004, 93, 105-113. [CrossRef]

56. Davignon, J.; Ganz, P. Role of Endothelial Dysfunction in Atherosclerosis. Circulation 2004, 109, III-27-III-32. [CrossRef]

57. Kibel, A.; Lukinac, A.M.; Dambic, V.; Juric, I.; Selthofer-Relatic, K. Oxidative Stress in Ischemic Heart Disease. Oxid. Med. Cell. Longev. 2020, 2020, 6627144. [CrossRef]

58. Shaw, J.; Anderson, T. Coronary Endothelial Dysfunction in Non-Obstructive Coronary Artery Disease: Risk, Pathogenesis, Diagnosis and Therapy. Vasc. Med. Lond. Engl. 2016, 21, 146-155. [CrossRef]

59. Tanabe, K.; Kawai, Y.; Kitayama, M.; Akao, H.; Ishida, R.; Motoyama, A.; Wakasa, M.; Saito, R.; Aoki, H.; Fujibayashi, K.; et al. Increased Levels of the Oxidative Stress Marker, Nitrotyrosine in Patients with Provocation Test-Induced Coronary Vasospasm. J. Cardiol. 2014, 64, 86-90. [CrossRef]

60. Yamada, S.; Saitoh, S.; Machii, H.; Mizukami, H.; Hoshino, Y.; Misaka, T.; Ishigami, A.; Takeishi, Y. Coronary Artery Spasm Related to Thiol Oxidation and Senescence Marker Protein-30 in Aging. Antioxid. Redox Signal 2013, 19, 1063-1073. [CrossRef]

61. Yasue, H.; Mizuno, Y.; Harada, E. Coronary Artery Spasm-Clinical Features, Pathogenesis and Treatment. Proc. Jpn. Acad. Ser. B 2019, 95, 53-66. [CrossRef]

62. Miyamoto, S.; Kawano, H.; Sakamoto, T.; Soejima, H.; Kajiwara, I.; Hokamaki, J.; Hirai, N.; Sugiyama, S.; Yoshimura, M.; Yasue, H.; et al. Increased Plasma Levels of Thioredoxin in Patients with Coronary Spastic Angina. Antioxid. Redox Signal 2004, 6, 75-80. [CrossRef]

63. Nishihira, K.; Yamashita, A.; Imamura, T.; Hatakeyama, K.; Sato, Y.; Nakamura, H.; Yodoi, J.; Ogawa, H.; Kitamura, K.; Asada, Y. Thioredoxin in Coronary Culprit Lesions: Possible Relationship to Oxidative Stress and Intraplaque Hemorrhage. Atherosclerosis 2008, 201, 360-367. [CrossRef] [PubMed]

64. Hokamaki, J.; Kawano, H.; Soejima, H.; Miyamoto, S.; Kajiwara, I.; Kojima, S.; Sakamoto, T.; Sugiyama, S.; Yoshimura, M.; Nakamura, H.; et al. Plasma Thioredoxin Levels in Patients with Unstable Angina. Int. J. Cardiol. 2005, 99, 225-231. [CrossRef] [PubMed]

65. Pizzino, G.; Irrera, N.; Cucinotta, M.; Pallio, G.; Mannino, F.; Arcoraci, V.; Squadrito, F.; Altavilla, D.; Bitto, A. Oxidative Stress: Harms and Benefits for Human Health. Oxid. Med. Cell. Longev. 2017, 2017, 8416763. [CrossRef] [PubMed]

66. Thomson, L. 3-Nitrotyrosine Modified Proteins in Atherosclerosis. Dis. Markers 2015, 2015, 1-8. [CrossRef]

67. Krasnow, N.; Neill, W.A.; Messer, J.V.; Gorlin, R. Myocardial lactate and pyruvate metabolism*. J. Clin. Investig. 1962, 41, 2075-2085. [CrossRef]

68. Kaikita, K.; Ishii, M.; Sato, K.; Nakayama, M.; Arima, Y.; Tanaka, T.; Sugamura, K.; Sakamoto, K.; Izumiya, Y.; Yamamoto, E.; et al. Determinants of Myocardial Lactate Production During Acetylcholine Provocation Test in Patients with Coronary Spasm. J. Am. Heart Assoc. 2015, 4, e002387. [CrossRef]

69. Suzuki, S.; Kaikita, K.; Yamamoto, E.; Jinnouchi, H.; Tsujita, K. Role of Acetylcholine Spasm Provocation Test as a Pathophysiological Assessment in Nonobstructive Coronary Artery Disease. Cardiovasc. Interv. Ther. 2021, 36, 39-51. [CrossRef]

70. Ludmer, P.L.; Selwyn, A.P.; Shook, T.L.; Wayne, R.R.; Mudge, G.H.; Alexander, R.W.; Ganz, P. Paradoxical Vasoconstriction Induced by Acetylcholine in Atherosclerotic Coronary Arteries. N. Engl. J. Med. 1986, 315, 1046-1051. [CrossRef]

71. Okumura, K.; Yasue, H.; Matsuyama, K.; Ogawa, H.; Kugiyama, K.; Ishizaka, H.; Sumida, H.; Fujii, H.; Matsunaga, T.; Tsunoda, R. Diffuse Disorder of Coronary Artery Vasomotility in Patients with Coronary Spastic Angina. Hyperreactivity to the Constrictor Effects of Acetylcholine and the Dilator Effects of Nitroglycerin. J. Am. Coll. Cardiol. 1996, 27, 45-52. [CrossRef]

72. Shokr, H.; Dias, I.H.K.; Gherghel, D. Microvascular Function and Oxidative Stress in Adult Individuals with Early Onset of Cardiovascular Disease. Sci. Rep. 2020, 10, 4881. [CrossRef]

73. Agrawal, S.; Mehta, P.K.; Bairey Merz, C.N. Cardiac Syndrome X: Update 2014. Cardiol. Clin. 2014, 32, 463-478. [CrossRef]

74. Seydi-Shirvani, S.; Rasmi, Y.; Seyyed-Mohammadzad, M.-H.; Khosravifar, F. Oxidative Stress Status in Patients with Cardiac Syndrome X. ScienceAsia 2012, 38, 136. [CrossRef]

75. Esterbauer, H.; Schaur, R.J.; Zollner, H. Chemistry and Biochemistry of 4-Hydroxynonenal, Malonaldehyde and Related Aldehydes. Free Radic. Biol. Med. 1991, 11, 81-128. [CrossRef]

76. De Gaetano, G.; Rajtar, G.; Livio, M.; Merino, J. Arachidonic Acid-Induced Malondialdehyde Formation in Rat Platelets. Kinetic Aspects and Inhibition by Acetylsalicylic Acid and Indomethacin. Naunyn. Schmiedebergs Arch. Pharmacol. 1980, 312, 85-89. [CrossRef] 
77. Yamashita, K.; Takahiro, K.; Kamezaki, F.; Adachi, T.; Tasaki, H. Decreased Plasma Extracellular Superoxide Dismutase Level in Patients with Vasospastic Angina. Atherosclerosis 2007, 191, 147-152. [CrossRef]

78. Ishii, M.; Seki, T.; Kaikita, K.; Sakamoto, K.; Nakai, M.; Sumita, Y.; Nishimura, K.; Miyamoto, Y.; Noguchi, T.; Yasuda, S.; et al. Short-Term Exposure to Desert Dust and the Risk of Acute Myocardial Infarction in Japan: A Time-Stratified Case-Crossover Study. Eur. J. Epidemiol. 2020, 35, 455-464. [CrossRef]

79. Deng, F.; Guo, X.; Liu, H.; Fang, X.; Yang, M.; Chen, W. Effects of Dust Storm PM2.5 on Cell Proliferation and Cell Cycle in Human Lung Fibroblasts. Toxicol. Vitro Int. J. Publ. Assoc. BIBRA 2007, 21, 632-638. [CrossRef]

80. Higashisaka, K.; Fujimura, M.; Taira, M.; Yoshida, T.; Tsunoda, S.; Baba, T.; Yamaguchi, N.; Nabeshi, H.; Yoshikawa, T.; Nasu, M.; et al. Asian Dust Particles Induce Macrophage Inflammatory Responses via Mitogen-Activated Protein Kinase Activation and Reactive Oxygen Species Production. J. Immunol. Res. 2014, 2014, 856154. [CrossRef]

81. Chuang, K.-J.; Chan, C.-C.; Su, T.-C.; Lee, C.-T.; Tang, C.-S. The Effect of Urban Air Pollution on Inflammation, Oxidative Stress, Coagulation, and Autonomic Dysfunction in Young Adults. Am. J. Respir. Crit. Care Med. 2007, 176, 370-376. [CrossRef]

82. Franchini, M.; Mannucci, P.M. Short-Term Effects of Air Pollution on Cardiovascular Diseases: Outcomes and Mechanisms. J. Thromb. Haemost. 2007, 5, 2169-2174. [CrossRef]

83. Lee, M.-S.; Eum, K.-D.; Fang, S.C.; Rodrigues, E.G.; Modest, G.A.; Christiani, D.C. Oxidative Stress and Systemic Inflammation as Modifiers of Cardiac Autonomic Responses to Particulate Air Pollution. Int. J. Cardiol. 2014, 176, 166-170. [CrossRef] [PubMed]

84. Huang, W.; Zhu, T.; Pan, X.; Hu, M.; Lu, S.-E.; Lin, Y.; Wang, T.; Zhang, Y.; Tang, X. Air Pollution and Autonomic and Vascular Dysfunction in Patients with Cardiovascular Disease: Interactions of Systemic Inflammation, Overweight, and Gender. Am. J. Epidemiol. 2012, 176, 117-126. [CrossRef] [PubMed]

85. Dominguez-Rodriguez, A.; Rodríguez, S.; Abreu-Gonzalez, P.; Avanzas, P.; Juarez-Prera, R.A. Black Carbon Exposure, Oxidative Stress Markers and Major Adverse Cardiovascular Events in Patients with Acute Coronary Syndromes. Int. J. Cardiol. 2015, 188, 47-49. [CrossRef] [PubMed]

86. Shao, D.; Oka, S.; Brady, C.D.; Haendeler, J.; Eaton, P.; Sadoshima, J. Redox Modification of Cell Signaling in the Cardiovascular System. J. Mol. Cell. Cardiol. 2012, 52, 550-558. [CrossRef]

87. De Geest, B.; Mishra, M. Role of Oxidative Stress in Heart Failure: Insights from Gene Transfer Studies. Biomedicines 2021, 9, 1645. [CrossRef]

88. Van der Pol, A.; van Gilst, W.H.; Voors, A.A.; van der Meer, P. Treating Oxidative Stress in Heart Failure: Past, Present and Future. Eur. J. Heart Fail. 2019, 21, 425-435. [CrossRef]

89. Ide, T.; Tsutsui, H.; Kinugawa, S.; Suematsu, N.; Hayashidani, S.; Ichikawa, K.; Utsumi, H.; Machida, Y.; Egashira, K.; Takeshita, A. Direct Evidence for Increased Hydroxyl Radicals Originating from Superoxide in the Failing Myocardium. Circ. Res. 2000, 86, 152-157. [CrossRef]

90. Holvoet, P.; Vanhaecke, J.; Janssens, S.; van de Werf, F.; Collen, D. Oxidized LDL and Malondialdehyde-Modified LDL in Patients with Acute Coronary Syndromes and Stable Coronary Artery Disease. Circulation 1998, 98, 1487-1494. [CrossRef]

91. Patel, R.S.; Ghasemzadeh, N.; Eapen, D.J.; Sher, S.; Arshad, S.; Ko, Y.; Veledar, E.; Samady, H.; Zafari, A.M.; Sperling, L.; et al. Novel Biomarker of Oxidative Stress Is Associated with Risk of Death in Patients With Coronary Artery Disease. Circulation 2016, 133, 361-369. [CrossRef]

92. Satoh, K.; Fukumoto, Y.; Sugimura, K.; Miura, Y.; Aoki, T.; Nochioka, K.; Tatebe, S.; Miyamichi-Yamamoto, S.; Shimizu, T.; Osaki, S.; et al. Plasma Cyclophilin A Is a Novel Biomarker for Coronary Artery Disease. Circ. J. 2013, 77, 447-455. [CrossRef]

93. Kotur-Stevuljevic, J.; Memon, L.; Stefanovic, A.; Spasic, S.; Spasojevic-Kalimanovska, V.; Bogavac-Stanojevic, N.; KalimanovskaOstric, D.; Jelić-Ivanovic, Z.; Zunic, G. Correlation of Oxidative Stress Parameters and Inflammatory Markers in Coronary Artery Disease Patients. Clin. Biochem. 2007, 40, 181-187. [CrossRef]

94. Huang, H.; Mai, W.; Liu, D.; Hao, Y.; Tao, J.; Dong, Y. The Oxidation Ratio of LDL: A Predictor for Coronary Artery Disease. Dis. Markers 2008, 24, 341-349. [CrossRef]

95. Aksoy, S.; Cam, N.; Gurkan, U.; Oz, D.; Özden, K.; Altay, S.; Durmus, G.; Agirbasli, M. Oxidative Stress and Severity of Coronary Artery Disease in Young Smokers with Acute Myocardial Infarction. Cardiol. J. 2012, 19, 381-386. [CrossRef]

96. Musthafa, Q.A.; Abdul Shukor, M.F.; Ismail, N.A.S.; Mohd Ghazi, A.; Mohd Ali, R.; Nor, I.F.M.; Dimon, M.Z.; Wan Ngah, W.Z. Oxidative Status and Reduced Glutathione Levels in Premature Coronary Artery Disease and Coronary Artery Disease. Free Radic. Res. 2017, 51, 787-798. [CrossRef]

97. Ehara, S.; Ueda, M.; Naruko, T.; Haze, K.; Itoh, A.; Otsuka, M.; Komatsu, R.; Matsuo, T.; Itabe, H.; Takano, T.; et al. Elevated Levels of Oxidized Low Density Lipoprotein Show a Positive Relationship with the Severity of Acute Coronary Syndromes. Circulation 2001, 103, 1955-1960. [CrossRef]

98. Garelnabi, M.; Gupta, V.; Mallika, V.; Bhattacharjee, J. Platelets Oxidative Stress in Indian Patients with Ischemic Heart Disease. J. Clin. Lab. Anal. 2010, 24, 49-54. [CrossRef]

99. Johnson, B.D.; Shaw, L.J.; Buchthal, S.D.; Bairey Merz, C.N.; Kim, H.-W.; Scott, K.N.; Doyle, M.; Olson, M.B.; Pepine, C.J.; den Hollander, J.; et al. Prognosis in Women with Myocardial Ischemia in the Absence of Obstructive Coronary Disease: Results from the National Institutes of Health-National Heart, Lung, and Blood Institute-Sponsored Women's Ischemia Syndrome Evaluation (WISE). Circulation 2004, 109, 2993-2999. [CrossRef] 
100. Groepenhoff, F.; Eikendal, A.L.M.; Rittersma, Z.H.S.; Gijsberts, C.M.; Asselbergs, F.W.; Hoefer, I.E.; Pasterkamp, G.; Rutten, F.H.; Onland-Moret, N.C.; Den Ruijter, H.M. Persistent Symptoms and Health Needs of Women and Men with Non-Obstructed Coronary Arteries in the Years Following Coronary Angiography. Front. Cardiovasc. Med. 2021, 8, 670843. [CrossRef]

101. Reriani, M.; Flammer, A.J.; Duhé, J.; Li, J.; Gulati, R.; Rihal, C.S.; Lennon, R.; Tilford, J.M.; Prasad, A.; Lerman, L.O.; et al. Coronary Endothelial Function Testing May Improve Long-Term Quality of Life in Subjects with Microvascular Coronary Endothelial Dysfunction. Open Heart 2019, 6, e000870. [CrossRef]

102. Emami, H.; Takx, R.A.P.; Mayrhofer, T.; Janjua, S.; Park, J.; Pursnani, A.; Tawakol, A.; Lu, M.T.; Ferencik, M.; Hoffmann, U. Nonobstructive Coronary Artery Disease by Coronary CT Angiography Improves Risk Stratification and Allocation of Statin Therapy. JACC Cardiovasc. Imaging 2017, 10, 1031-1038. [CrossRef]

103. Sedlak, T.L.; Lee, M.; Izadnegahdar, M.; Merz, C.N.B.; Gao, M.; Humphries, K.H. Sex Differences in Clinical Outcomes in Patients with Stable Angina and No Obstructive Coronary Artery Disease. Am. Heart J. 2013, 166, 38-44. [CrossRef] [PubMed]

104. Lee, K.Y.; Ong, T.K.; Low, E.V.; Liow, S.Y.; Anchah, L.; Hamzah, S.; Liew, H.B.; Ali, R.M.; Ismail, O.; Ahmad, W.A.W.; et al. Cost of Elective Percutaneous Coronary Intervention in Malaysia: A Multicentre Cross-Sectional Costing Study. BMJ Open 2017, 7 , e014307. [CrossRef] [PubMed]

105. Vassalle, C.; Bianchi, S.; Battaglia, D.; Landi, P.; Bianchi, F.; Carpeggiani, C. Elevated Levels of Oxidative Stress as a Prognostic Predictor of Major Adverse Cardiovascular Events in Patients with Coronary Artery Disease. J. Atheroscler. Thromb. 2012, 19, 712-717. [CrossRef] [PubMed] 